\title{
CONFLICTS OVER THE USE OF TERRITORY IN THE MINERAL AMAZON
}

\author{
PALHETA, João Marcio; ${ }^{a}$ * SILVA, Christian Nunes da; ${ }^{b}$ OLIVEIRA NETO, Adolfo; ${ }^{c}$ \\ NASCIMENTO, Flávio Rodrigues do; ${ }^{\mathrm{d}}$
}

\begin{abstract}
(a) Phd. in Geography, State University São Paulo Julio de Mesquita Filho, Presidente Prudente (UNESP/PP). Professor Federal Universsity of Pará (UFPa). http://lattes.cnpq.br/5356047514671129

(b) Phd. in Aquatic Ecology, Federal Universsity of Pará (UFPa). Professor Federal Universsity of Pará (UFPa). http://lattes.cnpq.br/4284396736118279 (c) Phd. in Geography, State University São Paulo Julio de Mesquita Filho, Presidente Prudente (UNESP/PP). Professor Federal Universsity of Pará (UFPa). http://lattes.cnpq.br/3108272104911953

(d) Phd. in Geography, Federal University Fluminenese (UFF). Professor Federal Universsity of Ceará (UFC). http://lattes.cnpq.br/3108272104911953
\end{abstract}

\section{(*) CORRESPONDING AUTHOR}

Address:-UFPA, Rua Augusto Correia, 1, CEP: 60075900, Belém (PA), Brasil. Tel: (+ 55 91) 32017106

E-mail: jmpalheta@ufpa.br

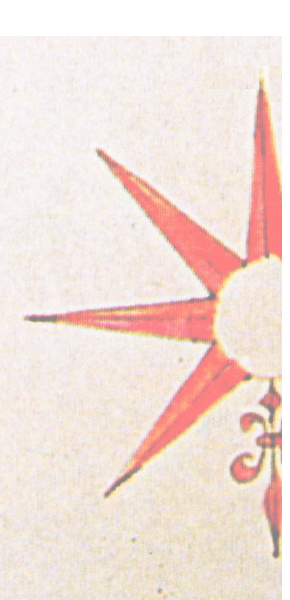

\section{ABSTRACT}

This work undertook an analysis of a territorial, political and economic cut, which we call the Region of Carajás, that is, where the largest mining projects of the Vale company are concentrated in the Southeast region of the state of Pará. The mineral province of Carajásis also considered, due to the effects of the mining activities; making it possible to carry out this cut in the municipalities (Parauapebas, Canaã dos Carajás, Marabá, Ourilândia do Norte, São Felix do Xingu and Curionópolis) where the largest Vale projects are concentrated, mainly from the first half of the twenty-first century. To this end, a geographic reading of the territorial transformations in Carajás and the reorganization of the territory were carried out, to think about the regional development articulated on different scales, provided by the mining activities in the state of Pará.

Keywords: Territory; Regional Development; Amazonia; Carajás.

\section{RESUMO/RESUMEN}

\section{CONFLITOS PELO USO DO TERRITÓRIO NA AMAZÔNIA MINERAL}

O esforço deste trabalho reside na análise de um recorte territorial, político e econômico, que aqui denominamos de Região de Carajás, ou seja, onde estão concentrados os maiores projetos de mineração da companhia Vale na região Sudeste paraense. Considera-se também a província mineral de Carajás, devido os efeitos das atividades mineradoras; o que permite fazer este recorte nos municípios (Parauapebas, Canaã dos Carajás, Marabá, Ourilândia do Norte, São Felix do Xingu e Curionópolis), que concentram os maiores projetos da Vale, principalmente, a partir da primeira metade do século XXI. Para isso, realizaremos uma leitura geográfica das transformações territoriais em Carajás e da reorganização do território, para pensar o desenvolvimento regional articulado em diferentes escalas, proporcionado pelas atividades mineradoras no estado do Pará.

Palavras-chave: Território. Desenvolvimento Regional.Amazônia.Carajás.

\section{CONFLICTOS POR EL USO DEL TERRITORIO EN LA AMAZONIA MINERAL}

El esfuerzo de este trabajo reside en el análisis de un recorte territorial, político y económico que aquí denominamos Región de Carajás, es decir, donde están concentrados los mayores proyectos de minería de la empresa Vale, en la región sudeste paraense. Se considera también, la Provincia Mineral de Carajás, debido a los efectos de las actividades mineras, lo que permite hacer ese recorte en los municipios (Parauapebas, Canaán dos Carajás, Marabá, Ourilandia del Norte, San Felix del Xingu y Curionópolis), que concentran los mayores proyectos de Vale, principalmente, a partir de la primera mitad del siglo XXI. Para ello, realizaremos una lectura geográfica de las transformaciones territoriales en Carajás y de la reorganización del territorio, para pensar el desarrollo regional articulado en diferentes escalas, proporcionado por las actividades mineras en el estado de Pará.

Palabras clave: Territorio; Desarrollo Regional; Amazonia; Carajás. 


\section{INTRODUCTION}

Thirty years have passed since the beginning of mineral exploration in Carajás, the largest reserve of mineral resources in the Amazon, in the Southeast of the state of Pará, in the northern region of Brazil. Since the 1980s, this part of the Amazon has become known as the region of Carajás, its municipalities have several mineral exploration projects under the command of Vale, the main mining company in the region. Since 1997 the company has entered a new phase, after being privatized by the Brazilian government it has become a large conglomerate operating in five continents.

The South-eastern region of the state of Pará, where the Carajás region is located, was once known primarily as an area of collection-extractivist activities, with an emphasis on Brazil nuts, and for being a region of agrarian conflicts involving several actors, such as landowners, land-grabbers, squatter-settlers, indigenous peoples, gold-diggers and Brazil nut harvesters. Important works by researchers in the Amazon address this issue, such as Hebette (2004a, 2004b, 2004c, 2004d) and Emmi (1988), Martins (1993), Velho (2009), among others.

With the introduction of industrial mining activities in the region there was a change in the region's role, both on the national and international scales, mainly due to the exploration of iron ore in the Ferro Carajás Project from 1985, as part of the Grande Carajás Program. However, the structure of domination and access to the use of the territories in the region remained unchanged, in many cases the old dynamics and agrarian conflicts that persisted in the region even accelerated.

Due to the installation of the project, the 1980s were a watershed for the Amazon region, especially the Southeast region of Pará. Various territorial, economic, social and political processes have emerged or have been accelerated by mining. The emergence of new municipalities, population growth, increased municipal revenues and increased social and environmental conflicts over land use demonstrate not only the complexity of these processes but also the complexity of the new territorial configuration that the Carajás region acquired after the installation of mining activities and activities related to them.

Several studies that deal with this theme have become obligatory reading on the region of Carajás and Southeast Pará, such as Hébette (1991), Castro; Moura and Maia (1995), Hall (1991), Coelho \& Cota (1997), Cota (1984), Becker (1982), Almeida (1993) and Pinto (2003, 1982), just to mention some of the interpretations that served as inspiration for the studies of the Amazonian region, which have been used as a reference for the writing of this brief essay on the territorial dynamics in Carajás. We will address some of the issues that are part of the debate about the region, briefly discussing the territorial, economic, social and political dynamics of the mineral activities in the region of Carajás.

Although we recognize that the Southeast region of the state defined by the IBGE and the region of integration of the State Government are explanatory for public policies, we have chosen another territorial, political and economic cut for our analysis, referred to herein as the Region of Carajás, where the largest Vale company's mining projects in the Southeast region of Pará are concentrated. The Carajás mineral province is also taken into consideration, as the effects of mining activities allow us to make this cut of the municipalities (Parauapebas, Canaã dos Carajás, Marabá, Ourilândia do Norte, São Felix do Xingu and Curionópolis) that concentrate the major Vale projects, mainly, from the first half of the twenty-firstcentury, and to try to make a geographic reading of the territorial transformations in Carajás and the reorganization of the territory, thinking about regional development articulated on different scales, provided by the mining activities in the state of Pará. 


\section{THE TERRITORY IN CARAJÁS ON THE THRESHOLD OF THE TWENTY-FIRST CENTURY}

Analyzing the appropriation of natural resources and considering the world economic system of capital, we can understand the territorial formation of the Southeast region of the state of Pará throughout its history, but mainly from the 1980s, when the large industrialization projects in the state's territory began. Carajás is a mosaic, a set of scenarios with distinct territories impacted (directly and indirectly) by mining activities, creating dynamics and territorialities, of which the economic are preponderant in the territorial transformations, on the municipal scale.

The characteristics of the territorialized production model lead to a local / global relationship being established, renewed around the complex articulation between the anchoring and the non-spatiality of production. In other words, the territory becomes a central space for coordination between the actors interested in solving unprecedented productive problems. We are, then, in the presence of a double combination between the anchored activity and nomadic activity of firms (PECQUEUR, 2009, p. 99).

In this way, the production model regionalized in the geographic space of Pará with territorial dynamics produced by mining activities have reorganized the production relations on different scales (whether local, national or international), which are part of the discourse of regional development created by the logic of the mining activities and the development poles based on the idea of the iron and steel industries, which were the starting point in understanding the use of the territory and its manifestations in the municipalities impacted by the mining activity in what we consider to be the Mineral Province of Carajás in the twenty-first century.

In this case, the economic organization of the territory is carried out from several determinants of the international market; and the minerals present in the province of Carajás (iron, copper, nickel, manganese, gold, for example) gain value and are used by the interest of this market that has created expectations about the wealth produced in the region, with the large-scale mineral extraction industry operating in the southeast of Pará. The increased value of the mineral products comes from supplying the market, which has directly and indirectly created an economic region formed to supply these markets.

A brief analysis of the data on the commercialization of the region's ores reveals that the wealth produced in Carajás leaves on the train wagons of minerals by the railroad, towards the port of Itaqui in the neighboring state of Maranhão, and is taken thousands of kilometers away, especially to Asia. Unfortunately, the prospects are not good in this scenario, especially with the expected expansion in the iron ore production of the S11D project in the municipality of Canaã dos Carajás, which has a high iron content and will increase the scale of production and, consequently, the socioeconomic conflicts in the area under its direct and indirect influence in the southeast region of Pará.

These processes of economic (re)organization of the territory due to the mining in the Southeast region, impelled and modified the functionality of the municipalities where mineral exploration was based, even when they did not actually create them. This induced new territorial dynamics, with demographic, financial, environmental, social, political reflections and amplified the conflicts that arose from old and new mining eras, before and after the democratic opening in the country.

\section{DEMOGRAPHIC DYNAMICS: GREED AND THE PRICE OF WEALTH IN CARAJAS}

Demographic growth in the municipalities of the Amazon region of Pará and the pre-Amazon state of Maranhão was driven by the search for jobs and better living conditions in mining activities or those generated by them in these geographic spaces. Even in different periods, either by gold-diggers prospecting or by the great projects of the time of the Great Carajás Program, the Southe- 
ast region of Pará is an area where population mobility was induced. Whether by road, rivers or railways, large population flows have moved in search of better days, resulting from the dream of wealth brought by mineral resources.

The territorial distribution of society in the Southeastern region of the state of Pará, mainly from the twenty-first century, began to concentrate in the cities and proximities where the mining activities or activities linked to them were installed. Even in the older municipalities where there are very expressive territorial dynamics that precede large-scale mining activities - such as Marabá, where the Carajás Iron Project was set up in the 1980s - territorial processes were boosted and accelerated by the dynamics of mining, such as the expansion of urban space and the fragmentation of the territory.

The new population dynamics and spatial reconfiguration in mining cities in the twenty-first century in Southeast Pará have as a direct and indirect influence the link between mining, energy, agribusiness, livestock and logging, which have attracted many people to the region in search of better conditions of life and work, accelerating the municipalities' socioeconomic transformations.

In this way, the new population flows have reconfigured the spatial distribution in the state territory, with a special emphasis on the large mining projects that, together with the attraction power of the jobs demanded by the mining activity, have contributed to accelerate the population growth in the cities that have mining activities. If the population growth in the state of Pará is compared with the evolution of Pará's population, in the 2000 census there were 6,192,307 inhabitants, ten years later the population reached a total of 7,581,051, and the IBGE estimate for the year 2015 was around 8,175,113 inhabitants, a significant growth in the state of Pará. Figure 1 shows the growth of the population in the state of Pará and the transition from the rural to the concentration in the urban geographic space. In 2016, there was an estimate and a projection that by 2030 the population of the state of Pará will reach 9,321,910 inhabitants.

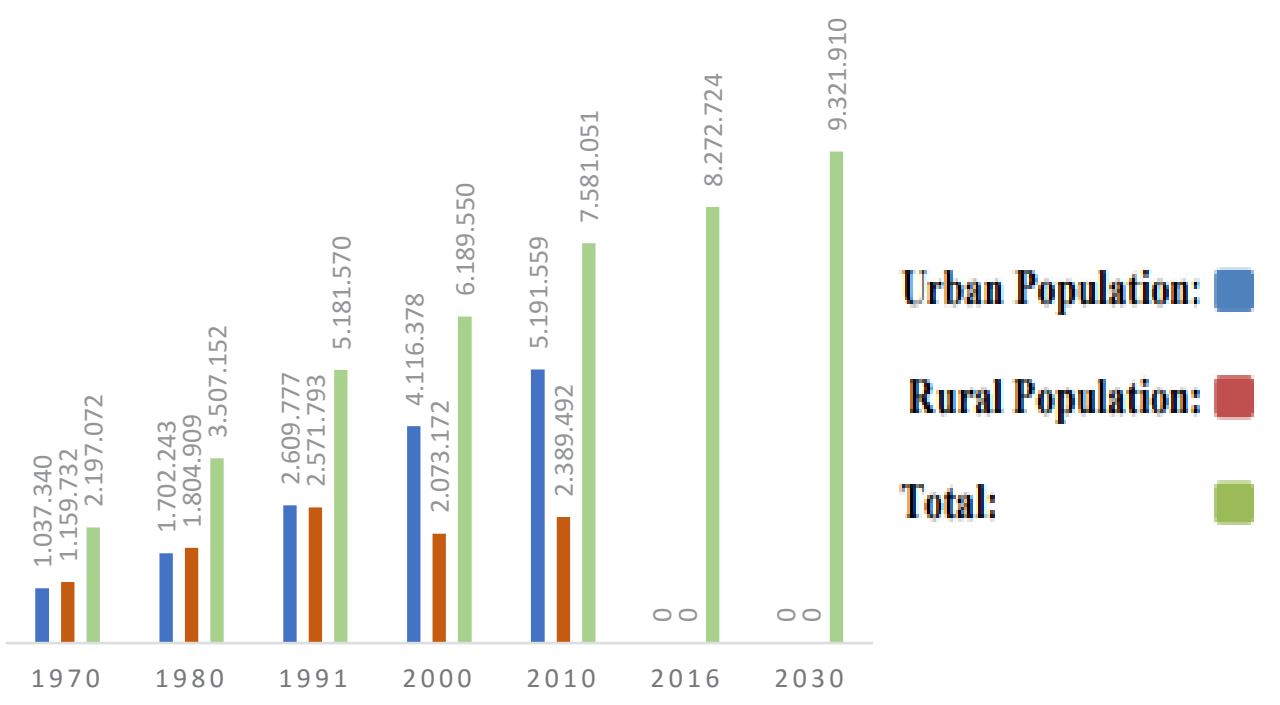

Figure 1 - Population of the State of Pará

Source: IBGE, Demographic Census 2010.

In the case presented here, in the society distributed in the state's five regions, in the Southeast region of Pará, especially in the six municipalities studied in the period from 2004 to 2015, the population grew by 368,126 people in 2004 , while the total population of the state of Pará rose by $6,482,055$. In 2014, the population of the six municipalities reached 650,309 inhabitants, while the total population of the state of Pará was 7,524,804 inhabitants. The municipalities of Marabá, Parauapebas, São Felix do Xingu and Canaã dos Carajás are highlighted in this population growth, directly and indirectly linked to mining activities (Figure 2). 


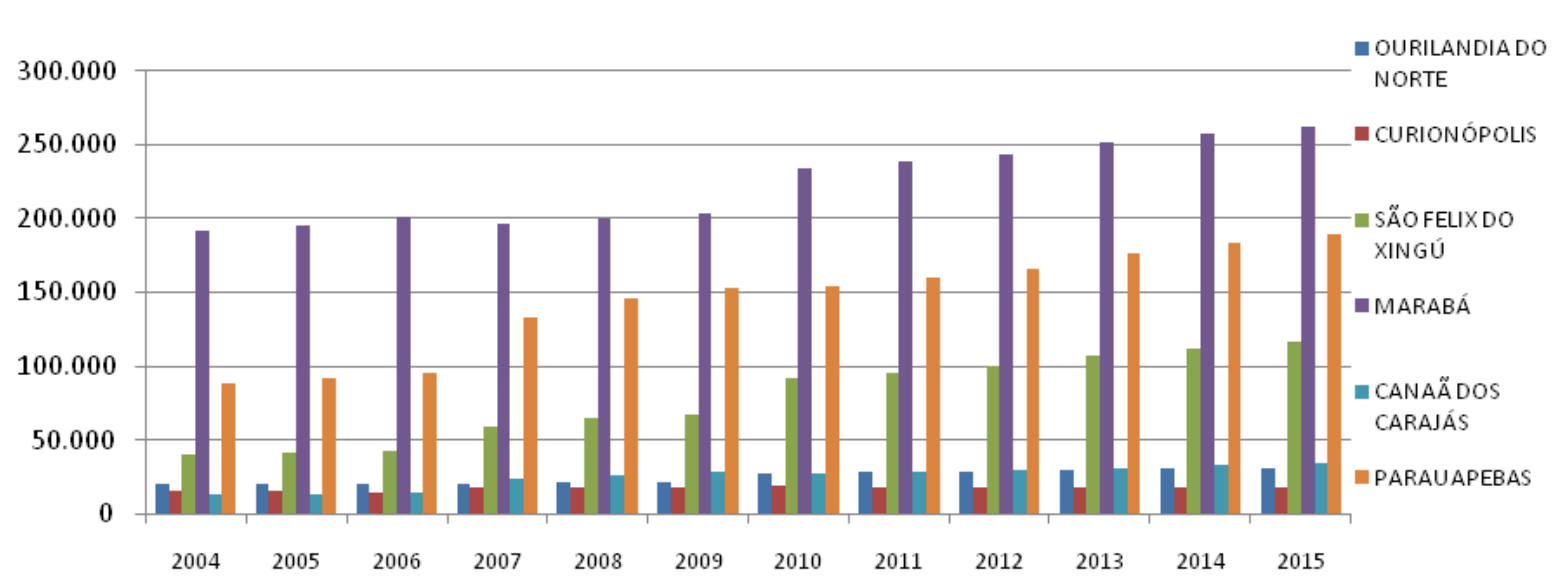

Figure 2 - Population of the six Mining Municipalities Source: IBGE - Demographic Census 2010* and Population Estimates.

Elaboration: FAPESPA (with adaptations by the authors).

Cities such as Parauapebas, Marabá and Canaã dos Carajás had a significant population growth, as demonstrated in the demographic data in graph 01 , the only exception being Curionópolis, ${ }^{1}$ where the population stagnated in this period. This population growth has been a constant phenomenon. Its urban centers have grown more than those in other cities in the southeast mesoregion, or even the majority of municipalities in the state of Pará. The problem of population growth in Brazilian cities that suffer impacts from mining is raised by Villa Verde, Alamino and Fernandes (2014), when they point out that,

These populations suffer mainly from problems arising from the way in which mineral enterprises are implanted, which is still far from the inclusive role they could best assume. This is the source of disorderly growth, bulging populations, inadequate infrastructure, impoverishment, etc. (VILLA VERDE, ALAMINO; FERNANDES, 2014, p.17).

This migratory flow towards mining cities has a direct impact on urban growth, especially on the outskirts of mining cities. An interesting recent study of the relationship between urban growth, peripheralization and the advancement of social inequalities can be found in Rodrigues (2015). One phenomenon that shows how the urban growth of these cities is marked by the intense migratory flow is the emergence of neighborhoods that are named after the places from which these people migrated. When they arrive in the mining municipalities, the process of occupation of the territory occurs with the construction of subnormal clusters (as characterized by the IBGE) or, as we prefer, clusters of exclusion, in which the occupation process is subject to every type of problem and social conflict. $^{2}$ The idea that the arrival of mining activities would reduce local and regional poverty is a lie. These cities are clear examples that in territories dependent on international dynamics and conditioned to the role of commodity producers, economic growth is accompanied by a growing peripheralization of the city, increased social-spatial inequality and intensified conflicts.

(1) The decline of the Serra Peladagold-digger prospecting in the 1980s and new projects in nearby towns were the main factors of population loss in the city.

(2) The idea of conflict in this essay takes into account that the society in conflict establishes guidelines to create the factor of social change, as part of the dynamics existing in the territory, which lead to social conflicts and, above all, the search for public policies to solve social conflicts through the differentiated use of the territory. 


\section{ECONOMIC DYNAMICS: FINANCIAL ASPECTS DRIVEN BY MINING}

The arrival of industrial mining activities in the Carajás region in the 1980s provoked profound transformations that accelerated population and economic growth and territorial fragmentation in the municipality. ${ }^{3}$ The territory hosting the arrival and installation of the Carajás Iron Project was one of the engines of these transformations along with the Serra Peladagold-digging in the 1980s and 1990s (SILVA, 2013).

The economic growth of the municipalities located in the state of Pará (Figure 3), especially where Vale's largest projects are concentrated in Carajás, was also important for the multiplication of services that this activity attracted, mainly to cater to new demands made by society, such as banks, health centers, commerce, and schools, among others. These services also indicated the growth of the city and the expansion of the neighborhoods, which began to emerge due to the demand from people arriving in search of work and better living conditions, and from companies providing services to mining activities.

The cities with large projects rely on the financial resources derived from mining activities, such as the Financial Contribution for the Exploration of Mineral Resources (CFEM), ${ }^{4}$ together with those from services (ICMS), population growth (FPM) and Taxation on Industrialized Products (IPI), which together helped increase municipal revenues and created expectations regarding the multiplication of existing services and the creation of other services for the communities living in these municipalities. One of the challenges of municipal public management is to translate these resources, which come directly and indirectly from mining, into social benefits for the societies affected by mining.

Figure 4, 5 and 6 show, respectively, the behavior of the municipal participation fund (FPM), the tax on goods and services (ICMS) and the tax on industrialized products (IPI) in the state of Pará.

The previous data show an indirect relation with mining, since they present data for the whole of the state of Pará and resources that are linked to general economic and demographic dynamics. In Figures 7, 8, 9 and 10 we show how this dynamic occurred in the municipalities under study, especially the increase in the financial income of these municipalities, which is represented by the CFEM, shown in Figure 7.

(3) The municipality of Marabá suffered two significant territorial losses. In 1988, Parauapebas (where the iron ore mine of Carajás was located) and Curionópolis, where the Serra de Peladagold-digging was located were removed from its territory (SILVA, 2013). These two municipalities removed from Marabá suffered new fragmentations, Parauapebas in 1993, with the loss of the territory where the municipality of Canaã dos Carajás is located nowadays, and Agua Azul do Norte (1991), and Curionópolis with the appearance of Eldorado dos Carajás in 1991.

(4) The CFEM, established by the 1988 Constitution, in its Article 20, paragraph 1, is owed to the States, the Federal District, the Municipalities, and the organs of the administration of the Union, as consideration for the economic use of the mineral resources in their respective territories, by the mining companies as a result of the exploration of mineral resources for economic use, on net sales, applying the rates of: $3 \%$ for: aluminium, Manganese, rock salt and potassium; $2 \%$ for: iron, fertilizer, coal and other substances; $0,2 \%$ for: precious stones, colored stones, carbonaceous and noble metals and; $1 \%$ for: gold (DNPM, 2016). 

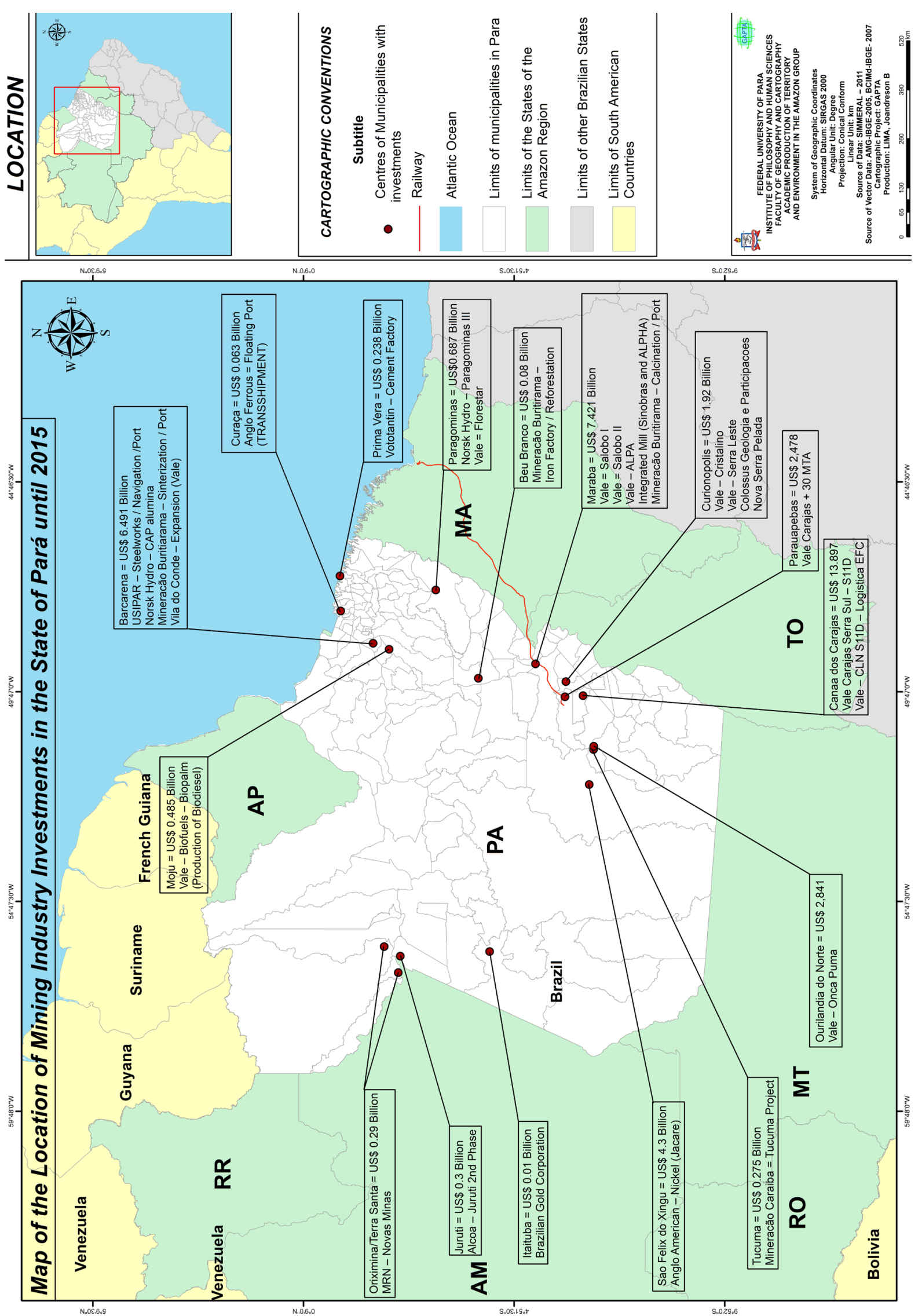

Figure 3 - Location Map of Mineral Industry Investments in the state of Pará (until 2015) 


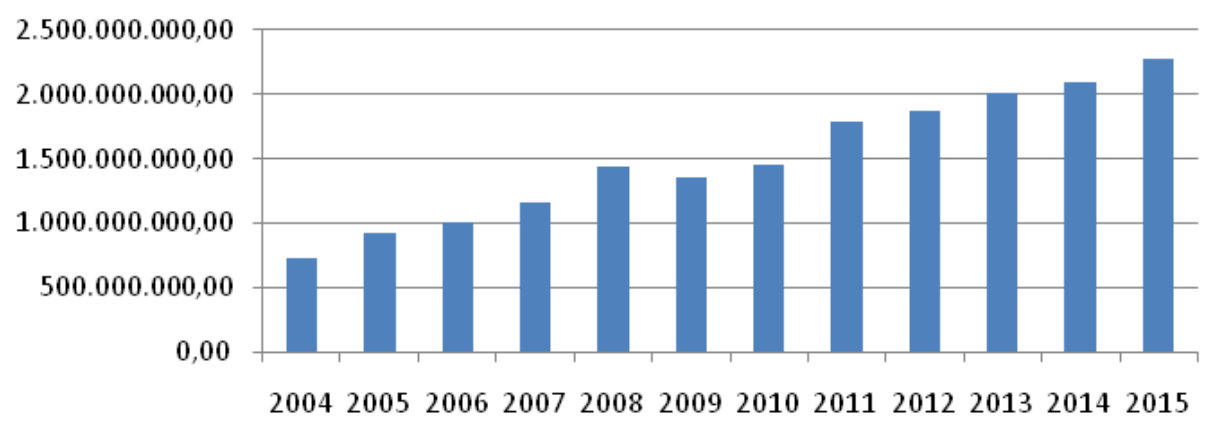

Figure 4 - Collection of FPM in the State of Pará Source: SEFA, 2016.

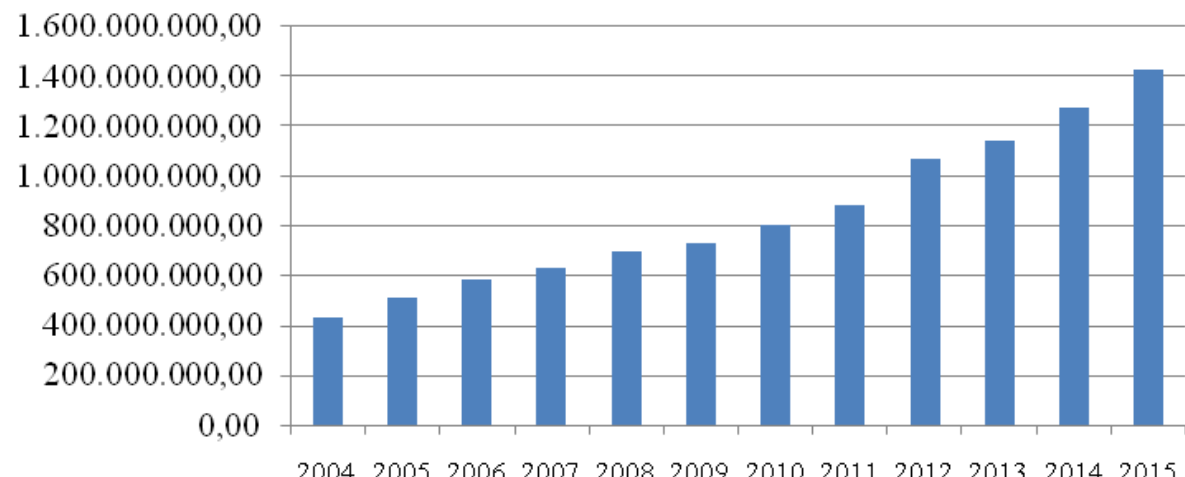

Figure 5 - Collection of ICMS in the State of Pará Source: SEFA, 2016.

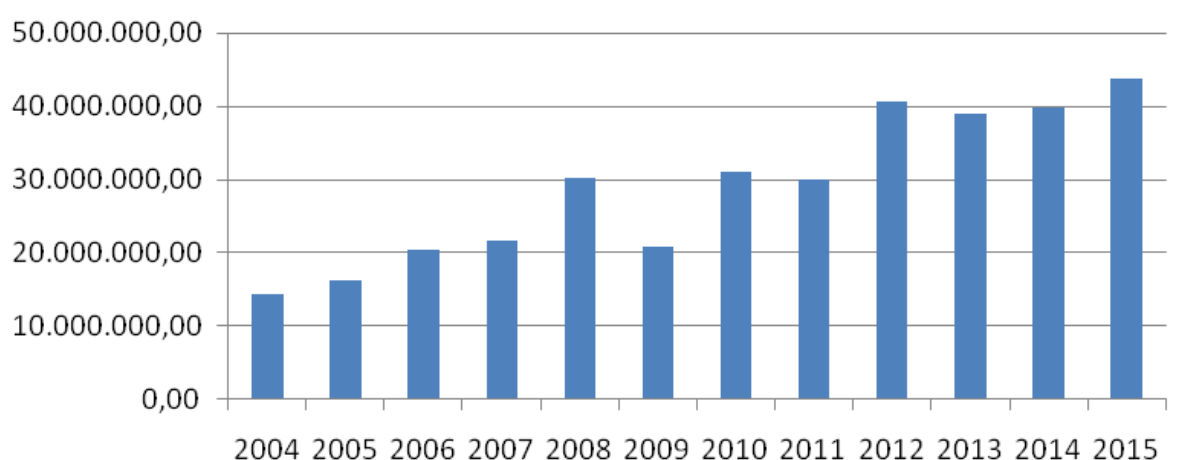

Figure 6 - Collection of IPI in the State of Pará Source: SEFA, 2016.

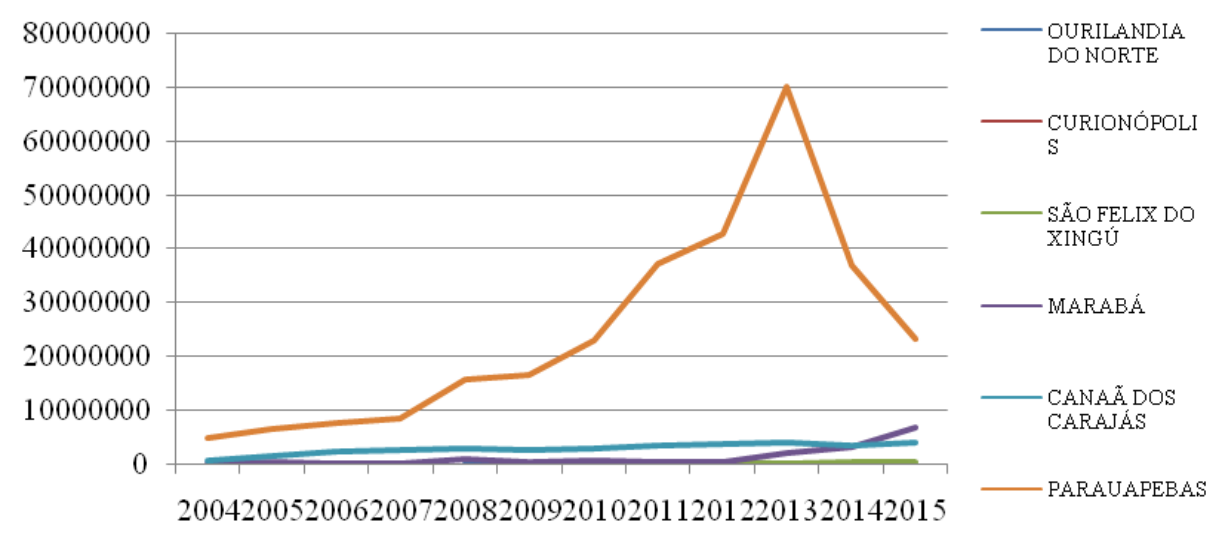

Figure 7 - CFEM collection in the municipalities studied Source: SEFA, 2016. 
Figure 6 shows the economic power generated by the Carajás iron ore mine, concentrated in the municipality of Parauapebas. Other municipalities with deposits being explored are Marabá, with the Salobo project and Canaã dos Carajás, with the Sossego project and the S11D. The CFEM is a local resource, since it is paid only to the mining municipality, unlike the data presented in Figures 8,9 and 10, which show an x-ray of regional economic and demographic dynamics, which in the case analyzed, is dynamized, mainly due to activities related to mining.

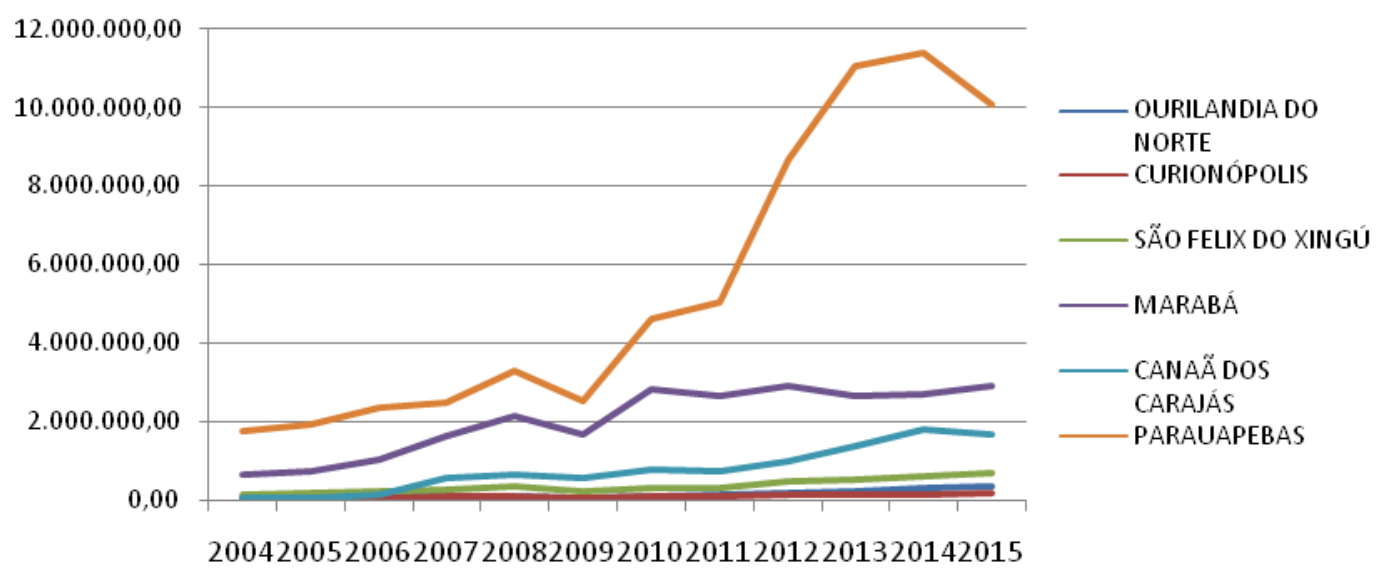

Figure 8 - IPI collection in the municipalities studied

Source: SEFA, 2016.

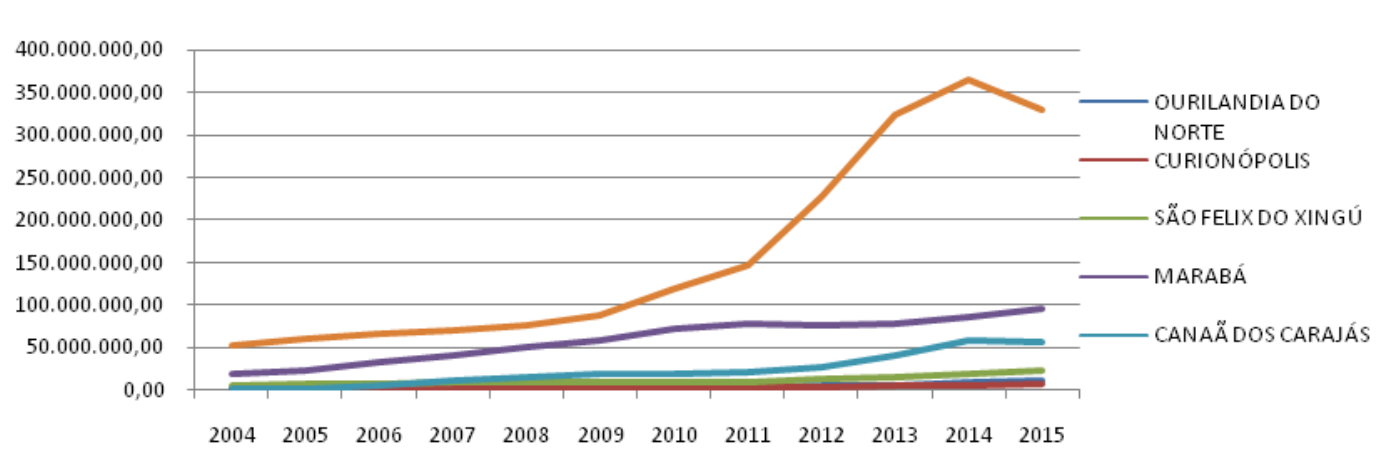

Figure 9 - Collection of ICMS in the municipalities studied

Source: SEFA, 2016.

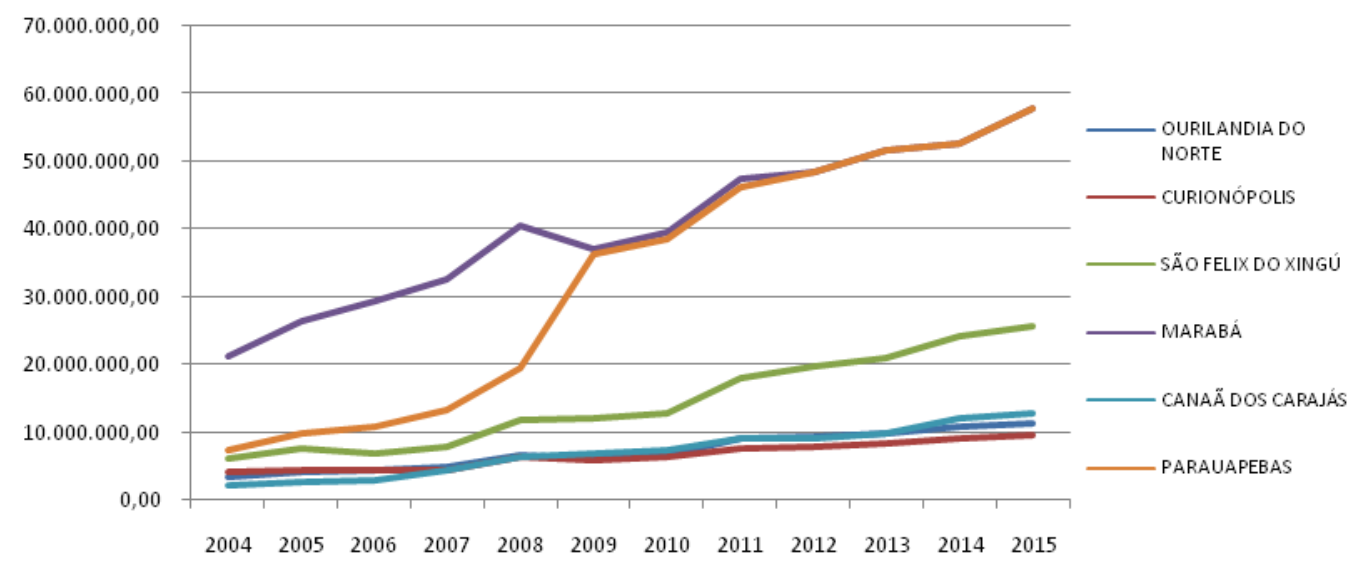

Figure 10 - Fund for the Participation of Municipalities Studied

Source: SEFA, 2016.

Data analysis shows that mining activities generate direct resources related to the extraction of ore and indirect resources related to the industrialization, circulation, population attraction and 
dynamization of the regional economy. However, this increase in resources is the great favorable argument that links the discourse related to mining with the debate about development, placing the latter as the result of the appropriate use of the resources generated by the former. Positions like this state that:

Mineral activities are able to revert benefits to the population of the municipality where they take place. This depends on a governance committed to the diversification of the economy and an infrastructure that arises from, especially: efficient transport modes, education, technological training and health and sanitation services. These assumptions are capable of positively impacting not only on the acceleration of human development but also the minimization of the negative social-environmental impacts of mineral extraction activities (VILLA VERDE, ALAMINO, FERNANDES, 2014, p.20).

The idea that mining cities were places where money and jobs circulated attracted both companies and people to the region for the virtual demand for services and jobs that these cities disseminated nationally and regionally, divulged in the local, regional, national and international media. (Figure 11). The installation of the mining projects attracted labor with the most diverse levels of qualifications. The great majority were poorly qualified, resulting in a phenomenal reserve army, leaving a multitude of unemployed, underemployed and autonomous workers, mainly among those who came in the first phase of the project. Most of the time these subjects were left to contemplate hope from the periphery of the cities.

The increase in municipal revenues was driven by the demand of the international market, which had positive effects on the Brazilian and the state of Pará's trade balance with the export of commodities. In 2015, exports from Pará state reached US \$ 10.272 billion, with mining accounting for US \$ 8.660 billion, or 84\%, 3 (SIMINERAL, 2016). Iron ore was mainly responsible for these numbers, followed by copper. In other words, Parauapebas and Canaã dos Carajás were cities that contributed to Pará's trade balance and accelerated the expectations of the multiplication of wealth in the region, especially with the news of new mining projects.

From the data for production, resources and employment, the embryo of a geo-economic region thought of in the early 1980s became a possible dream, even with all the problems and conflicts that multiplied with the presence of mining activities in the territory of Pará. At the beginning of the twenty-first century Carajás was the pioneer in the mining investments in Brazil, mainly with the S11D project of iron exploration in the municipality of Canaã dos Carajás. Before this Canaã also experienced the installation of the copper project, which decisively transformed its economic activity from agriculture to mining, changing the functionality of the municipality and making the city one of the biggest employers in the country, due to the demand from both the copper and iron projects in the municipality (Você $\backslash \backslash A, 2016)$. Six municipalities (Parauapebas, Marabá, Canaã dos Carajás, Ourilândia do Norte, Curionópolis and São Felix do Xingu) received investments in the Vale company's mining projects.

Marabá was the first municipality to receive investments in the region, still in the 1980s, with the PFC, along with this mining project the Serra Pelada was discovered, which helped to drive the territorial transformations in the municipality. Later these two areas were removed from its territory repositioning the municipality in the totals for demographics and revenue (Silva, 2013) - even though the municipality has maintained its importance in the regional context, which has been in place since the time of the Brazil nut harvesting (EMMI, 1999) - and continued with the Salobo project (exploration of copper ore) implanted in the municipality, on the border with Parauapebas.

Marabá still lives in the constant expectation of the construction of a steel pole in the city, with the virtual creation of the AçosLaminados do Pará (ALPA) factory and the project to create a flat steel mill. The implementation (or not) of these projects in the city reignites the debate on the impacts that these projects will have on the location and the region, mainly due to the already accelerated migratory flow that the municipality receives. Economic interests stand out because 

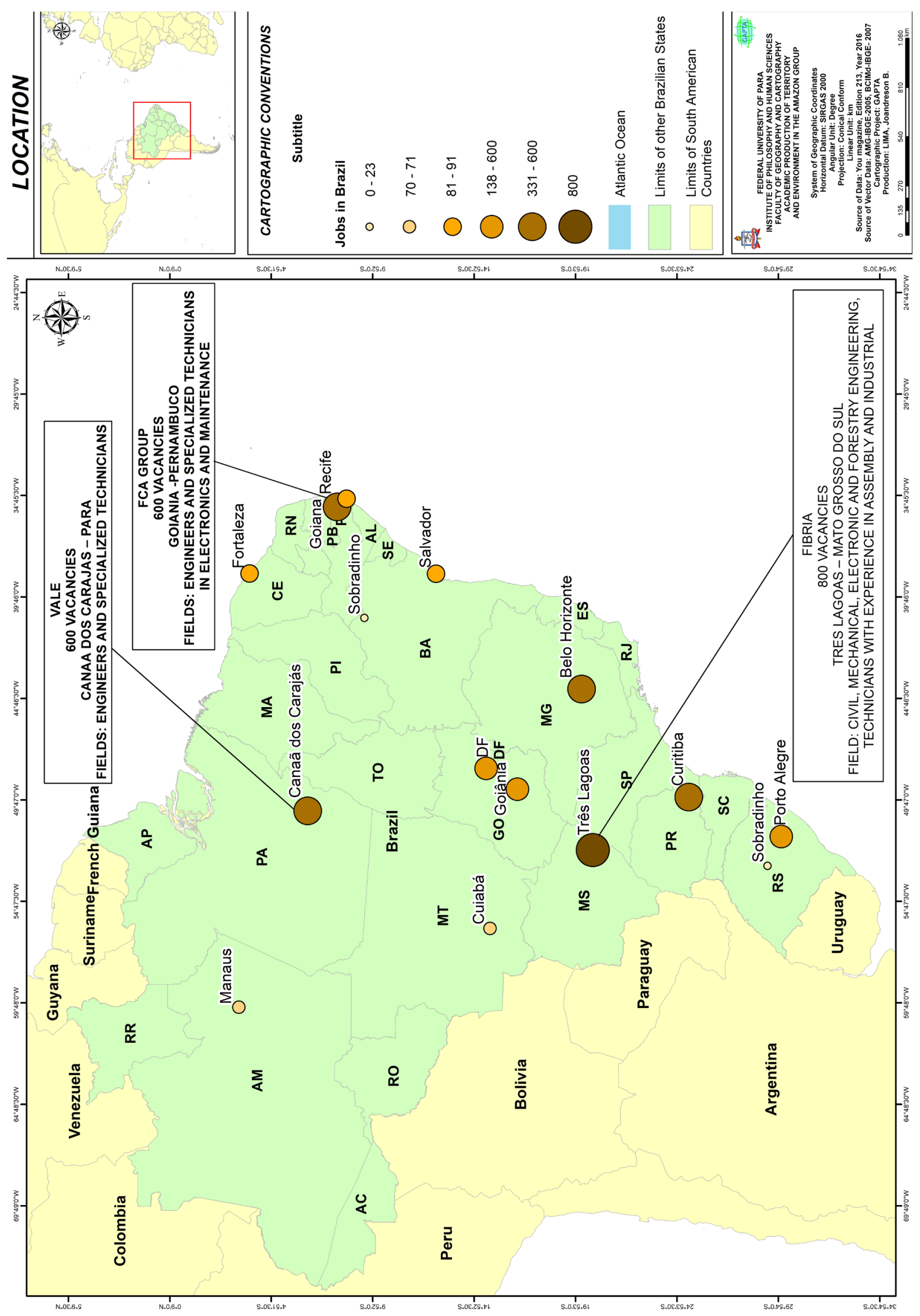

Figure 11 - Map of jobs in Brazil 
of the old dilemma regarding the dependence of the local economy on mining activities - even in municipalities like Marabá, which have a diversified economy and do not depend exclusively on mineral sector investments - showing that mineral exploration and action of the big companies can impose themselves as the main economic dynamic and regional development strategy.

The loss of population and revenue from two important sources of income for the municipality of Marabá was due to the iron mine ending up in the territory of the municipality of Parauapebas, from 1988, and the gold prospecting of Serra Pela being added to the newly created municipality of Curionópolis. The two cities emerged as a reflection of the mineral exploration in the region, one due to planned industrial mining and the other due to the experiences of gold-diggers in the region, without any planning.

The municipality of Parauapebas continued its economic dynamism with the presence of mainly iron ore mining, expanding its exploration through new iron and manganese mines operated in the municipality by Vale, called the Carajás iron mine and the Blue Mine respectively, which together boosted the economy in the municipality through direct and indirect revenue related to mining activities.

In turn, since 2004, Canaã dos Carajás has changed radically in its conception of its economic development, becoming directly dependent on the actions of the copper project (SILVA, 2013). Expecting to multiply its resources with the S11D Iron Project, which is scheduled to come on stream in 2016, the city has registered a significant increase in the number of jobs (Figure 12) and population growth, with the emergence of many neighborhoods, but also with a differentiated participation by Vale in the municipality, unlike in Parauapebas.

30.000

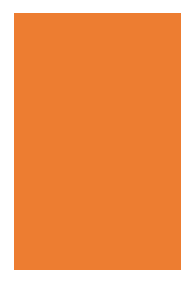

Peak Works
2600

Operation Phase

Figure 12 - Estimated Job Creation of the S11D Project

Source: Vale, 2012.

From a typical agricultural city born from the CEDERES ${ }^{5}$ when it still belonged to Marabá, and later to Parauapebas, in the 1980s and 1990s, at the beginning of the twenty-first century Canaã dos Carajás changed its functionality, becoming a city whose relationship is directly linked to mining. The migration to the city was mainly attracted by the jobs created by Vale and the companies that provide services to the copper (Serra do Sossego) and iron (Project S11D) projects.

These mining enterprises in the municipality of Canaã dos Carajás will continue to create new economic dynamics and accelerate the territorial transformations, with the creation of new infrastructures to meet the demand for services for the sectors of society, which begin to use the territory of the municipality in different forms and, consequently, placing new pressures on this territory through new economic and social demands, accelerating the transformations in the municipality even more.

Another municipality whose territorial dynamics has oscillated is Curionópolis, which experienced a "gold fever" at the height of the Serra Peladagold prospecting in the 1980s. After the peak of the gold-digging, it went through a deep economic and demographic stagnation, losing population due to the economic dynamics that could not generate or maintain the same amount of jobs in the

(5) The Center for Regional Development, created to meet the agricultural demand of major projects in the 1980s, in the region of Carajás. 
municipality. With the Canadian company Colossus' attempt to industrialize the gold-digging in the 2000s, the hope for mining was revived in the municipality. With the problems that arose and the company's exit, the municipality still had hope in the Vale's Serra Leste project.

The municipalities of Ourilândia do Norte and São Felix do Xingut have in their territories one of the largest "iron-nickel production plants ${ }^{6}$ in the world " acquired by Vale in 2005. The company is the second largest nickel producer on the planet and has operations in several countries such as Canada, Indonesia, New Caledonia, and refineries in the United Kingdom, Japan, Taiwan and China. It is the first nickel operation in the country, with a capacity of 200,000 tons of iron-nickel and 53 of nickel, with investments of US \$ 2.84 billion generating 1500 jobs. Its operation takes place via the Carajás Railroad ${ }^{7}$ to be exported to Asia and Europe.

\section{DYNAMICS OF SOCIAL CONFLICTS IN MINING AREAS}

Parallel to economic growth, mining has a perverse side, which in the case of Pará is no longer an "unexpected effect" and has become an almost sine qua non effect of the activity. Even considering the economic dynamism derived from the mining activity, it is fundamental to analyze the weight that environmental, political, cultural and social issues have in the balance so as to debate the future of this activity in the region, since we consider it impossible to consider the next hundred years of the territory without considering the weight that this activity has.

The analysis of the role that mining has in the territorial dynamics has to take into account a set of elements. First, the diversity, quality and quantity of mines mapped in the territory. In addition to having the largest iron ore and copper deposits in the world and having one of the biggest gold deposits in its time, Pará still has significant deposits of aluminum, kaolin, nickel, bauxite, tin, limestone, copper, iron and gold. This scenario makes clear the need to necessarily associate the debate about the future of the territory of Pará to mining.

The second element is the dependent nature of our economy. Dependent on large mining companies and fluctuations in the international market, which worsen in the mining territories due to the power that this activity has to create super-specialized economies, largely dependent on a single driving activity.

In the case of Pará, industrial mining takes place alongside gold-digging mining. In the first instance, the big companies in the sector have been working to transform our subsoil into a stock of resources that are connected in command, control and circulation networks with points on several continents, as is the case of Vale. They activate and deactivate the use of these deposits or the level of extraction depending on the result of an equation that relates local constraints (cost of labor, environmental issues and cost of logistics, among others) and global constraints (markets, exchange rates of national currencies and the supply of ores in the market, among others).

Gold-digging mining has another dynamic. Marked by artisanal or semi-artisanal forms, it is characterized by the massive use of manpower that is used at absolutely exhaustive levels and has violence and control as the two main poles of the same process: the control of mineral exploration. Also worrying is the amount of waste and heavy ores discarded in the water table.

As they exploit the deposits, mining activities disregard anything on the surface. The experience in Pará has shown that with each new deposit of ore discovered, new forms of conflict arise, creating conflicts on a local scale between the exploration of the subsoil and the reproduction of traditional territories, conflicts between the exploration of the subsoil and the previous territorial

(6) Nickel is a metal resistant to an oxidation and corrosion used to form alloys with various utilities in industry. Its largest consumption is by the steel industry, with $63 \%$ of the metal being used to produce stainless steel. Around $95 \%$ of Onça Puma's production will be destined to the foreign market, aiming to serve countries like China, Japan, Germany, Finland, Italy and United States, among others. (Http://www.omcconsult.com.br/noticias/vale-inaugura-primeira-planta-de-ferro-niquel-do-brasil/. Accessed on November 6, 2016).

(7) Vale is also adapting part of its wagons on the Carajás Railroad (EFC) to meet the production from Onça Puma. Since almost all the production of iron-nickel will be destined to export, transport occurs in containers that facilitate the distribution of the product, taking care of the logistical needs of this market (http://www.omcconsult.com.br/noticias/vale -first-plant-of-ironnickel-of-Brazil /). Access in: 06nov. 2016. 
dynamics and, finally, conflicts between the exploration of the subsoil and the ecosystem, as succinctly presented in Figure 13.

We also briefly describe how the conflicts are expressed on a regional scale, impacting beyond the places where the deposits are located, especially from the installation of infrastructure plants, logistics plants and industrial plants.

In different municipalities, mining activities have created conflicts with collector-extractivists, quilombolas, small farmers, riverine people, artisanal fisherfolk and indigenous peoples. In general, these subjects have found it very difficult to reproduce their territorial dynamics after the installation of mining activities. The impact on their territory is not always recognized by the State and the company, leaving them without any kind of economic compensation. In other cases, even economic compensation has not been able to prevent the unraveling of the social relations of these groups who suffer from the abrupt modification of their identities and territorial dynamics.

In towns such as Almeirim, Cachoeira do Arari, Barcarena, Porto de Moz, Itaituba, Moju Altamira and Ulianópolis, quilombolas, extractivists, riverine communities and artisanal fishermen have been directly impacted by mining activities in their territories, whether by the installation of mines, pipelines, power transmission, waterways, hydropower or ports. In municipalities such as São Félix do Xingu, Altamira, Ourilândia do Norte, Marabá and Itaituba conflicts over land tenure and violence in the countryside have intensified, as well as the difficulty of guaranteeing legal ownership to smallholders who are threatened by the advance of mining in the region. In indigenous municipalities such as Itaituba, Altamira, Tucuruí, Bom Jesus do Tocantins, Parauapebasand Ourilândia do Norte, indigenous peoples resist the installation of mining activities in their territories by large companies or by the illegal mining of gold-diggers. In other cases, they fight for compensation for the impacts generated by these activities. In this case, the last case, it is clearly stated that the existing dispute is between the process of appropriation of the subsoil and the traditional use of the territory. On the agenda are respect for material elements, such as the house, the river, and the forest, for example, and immaterial elements such as memory, history and social representations, among others.

At the same time, deforestation, the pollution of water resources, soil and air, the accumulation of waste, the disrespect of the limits established for Environmental Protection Areas (APA), Extractive Reserves (RESEX) and Indigenous Lands (TI) and the deterioration of environmental comfort are some of the environmental dimensions of the conflict and have been an emerging agenda, gaining more space in the mobilization of various subjects.

Processes such as the forced removal of traditional peoples and citizens in general, the lack of progress in advancing the recognition of land tenure and ensuring an effective land regularization policy for traditional peoples and small farmers, the increased violence in the countryside, in the city and for the control of areas of mineral extraction, social-spatial segregation, peripheralization in the cities and the hypertrophy of public services are constantly exacerbated and intensified, showing that mining activity has historically advanced in the region, from the combination of the primitive permanent process of capital accumulation and the process of accumulation by spoliation. In areas where the activity does not progress under the flag of force and violence, it advances as legitimized looting by a political and legal structure that, in general, leaves very little for the local communities, besides the craters and environmental impacts, of course.

The Carajás region is a good synthesis of this process. With activities developed from industrial mining, there are a wide variety of conflicts that are the direct result of the mining activity that is developed from the logic of accumulation by spoliation, even if the discourse is based on ideas such as environmental and social responsibility. Figure 14 presents a summary of these conflicts.

The diversity and quantity of ores are directly linked to the breadth and complexity of the conflicts in the region. The increase in violence in the countryside, which has in fact never ceased, the territorial disputes between companies and the population, the clash over the compensation 


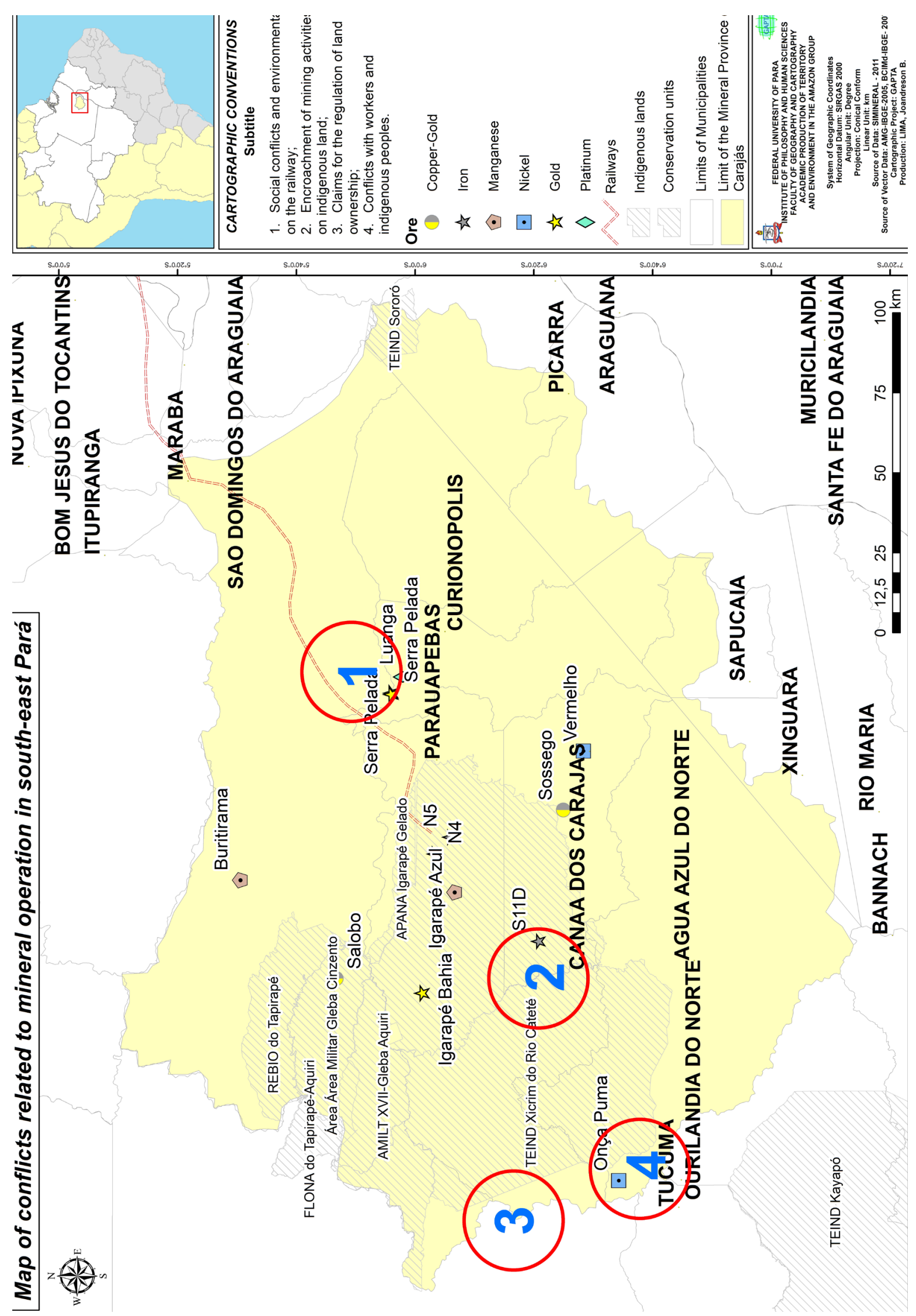

Figure 13 - Map of the location of deposits and the conflicts generated 

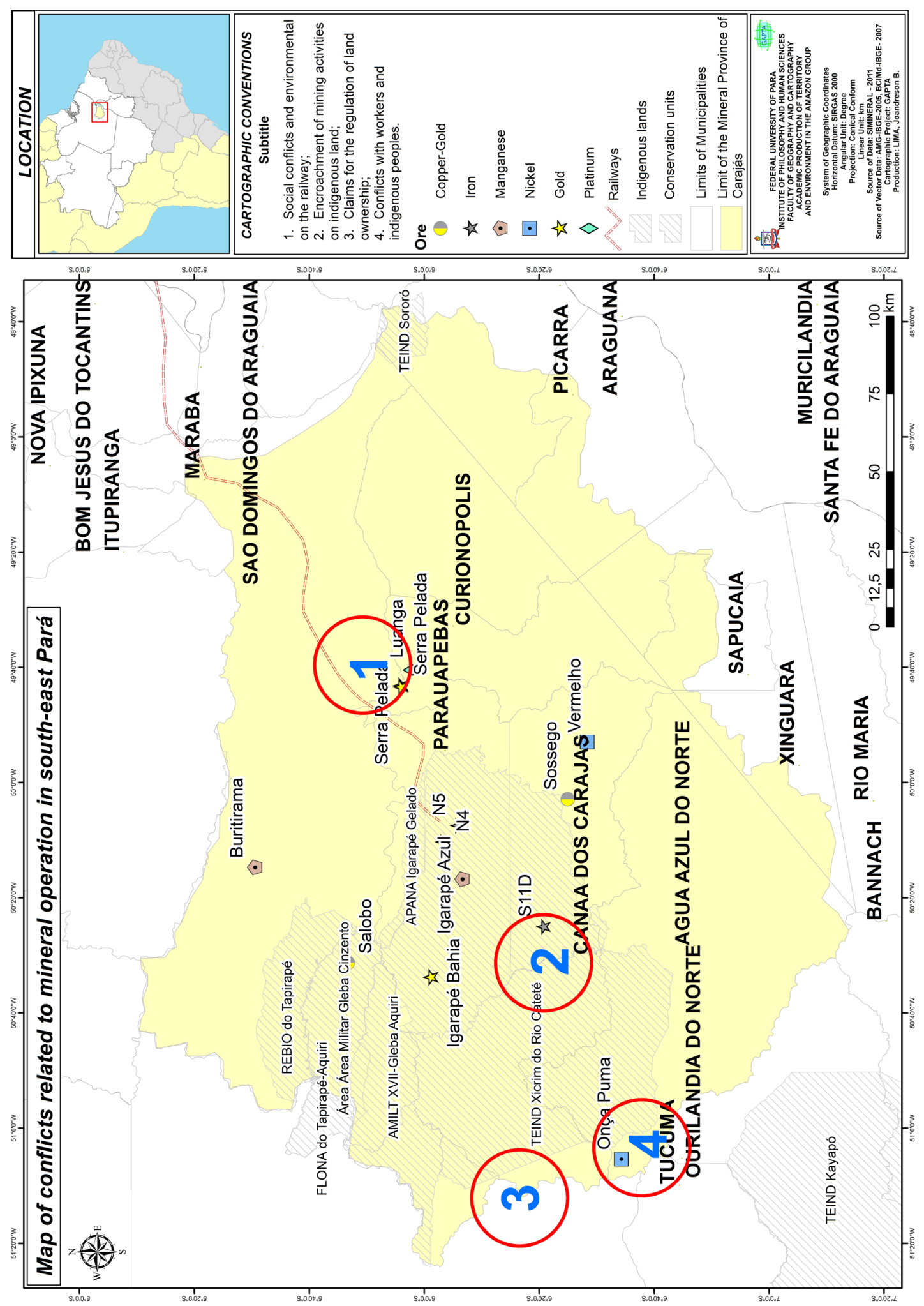

Figure 14 - Map of conflicts related to mineral operation in south-east Pará

and taxes generated by mining activities, as well as the use of these resources, the accumulation of environmental impacts and the constant persecution and judicialization of the struggle against mining companies have shown that the promises of progress have never been fulfilled and mining has become a decoy for a large part of the population, bringing to the fore the need to reassess the future of mining in the state. 
The debate that associates mining with development, placing in the central axis of the political agenda claims related to royalties, taxes and the verticalization of production, has run out faster than the deposits and has shown an ideology that omits the two elements that must be central: the control of the territory and the democratization of mineral wealth.

\section{FINAL CONSIDERATIONS}

The economic dynamic that has produced new territorialities in the Southeast region of Pará in the twenty-first century challenges public managers to jointly promote the much desired and virtual regional development. The extractive dynamics that persist in the southeastern region of Pará, allied with agriculture and logging, coupled to the new era of agribusiness, have multiplied the complexity and possibility of new conflicts and continue to make the region one of the most problematic in social conflicts in the country, due to the contradictory uses of territory.

The intensification of agrarian conflicts, disorderly migration, urbanization without quality public services, whether in the center or on the outskirts of mining cities, raise questions about the role of mining activities in local and regional development. We are far from using the riches in the territory in favor of the societies directly affected, unless we solve problems of the past first, that point to new conflicts of mining in the future, if we are actually going to have a future of the mining in the region of Carajás. At the mercy of the international market and its demands, the region did not awaken to transient mining (short, medium and long term); with the local economy highly dependent on the dynamic of mining, which in turn is directly derived from the international market.

These six municipalities (Parauapebas, Canaã dos Carajás, Marabá, Ourilândia do Norte, São Felix do Xingu and Curionópolis) form the area of Southeast Pará that concentrates the largest and most important Vale projects in the state of Pará, connected to the international scale and the driving force of a regional geo-economic mining region. We understand that mining is not the only creator of dynamics and that before the arrival of the large-scale mining, the Southeast region had already suffered other dynamics such as those related to activities such as cattle raising and brazil nuts, for example, but it is with mining that the region won the status of a promising economic region to serve the world market, due to mineral resources.

The question now posed is to try to understand the true social-environmental cost involved in mining activities and whether this account is being or can be paid one day in its right measure, especially considering that several elements that are impacted directly by mining cannot be, on the one hand, monetizable and, on the other, affect not only the present generations, but also the previous ones (when history and memory of places are lost) and future ones.

A reassessment of the history of mining activity in the region and a review of current socioeconomic conditions and human development indicators allow us to admit that the model used in the region is a strange model of pure wealth generation, directly linked to the interests of the companies and subjects that control the companies, without any ethical, moral or environmental commitment with the territories that have been abruptly ruined. Once the ideological discourse that sustains it is undone, mining in the region ceases to be a path to development and has become a decoy.

Discussing mining just from the perspective of the generation of jobs, compensation, taxes and the verticalization of production, as already stated, does not respond to the current moment. This discourse reached its limit when we evaluated that four decades of mining in the Carajás region, based on this debate, generated the growth of finances in the municipalities, however, it was not enough to reduce poverty, to stop conflicts or to allow a significant improvement in the quality of life of the local population. It is necessary to renew the debate and the political struggle, reaffirming the importance of local development, taking into account the debate on the control of the territory and the democratization of the mining activity. 


\section{BIBLIOGRAPHICAL REFERENCE}

ALMEIDA, A. Carajás: a guerra dos mapas. Belém: Falangola Editora, 1993.

BECKER, B. Geopolítica da Amazônia: a nova fronteira de recursos. Rio de Janeiro: Zahar Editores, 1982. CASTRO, E.; MOURA, E.; MAIA, M. Industrialização e grandes projetos: desorganização e reorganização do espaço. Belém: EdUFPA, 1995.

COELHO, M. C. N.; COTA, R. G. (Orgs.). 10 anos da estrada de ferro Carajás. NAEA/UFPA, 1997.

COTA, R. Carajás, a Invasão Desarmada. São Paulo: Vozes, 1984.

EMMI, M. F. A oligarquia do Tocantins e o domínio dos castanhais. Belém/PA: EDUFPA, 1988.

HALL, A. Amazônia: Desenvolvimento para quem?:desmatamento e conflito social no Programa Grande Carajás. Rio de Janeiro: Jorge Zahar Editor, 1991.

HÉBETTE, J. Cruzando a fronteira. Belém: EDUFPA, v. I, 2004a.

HÉBETTE, J. Cruzando a fronteira. Belém: EDUFPA, v. II, $2004 \mathrm{~b}$.

HÉBETTE, J. Cruzando a fronteira. Belém: EDUFPA, v. III, 2004c.

HÉBETTE, J. Cruzando a fronteira. Belém: EDUFPA, v. IV, 2004d.

HÉBETTE, J. O Cerco está se fechando: o impacto do grande capital na Amazônia. Belém: NAEA/UFPA, 1991.

LONGE das Capitais. Mercado interior. São Paulo: Revista Você $\mathbf{S} \backslash \mathbf{A}$, abril de 2016. Edição 213. Pag. 48-52. PECQUEUR, B. A guinada territorial da economia global. Política \& Sociedade, $n^{\circ} 14$ - Florianópolis,abril de 2009,p. 79-105. Disponível em:<https://periodicos.ufsc.br/index.php/politica/article/download/11615/10955>. Acesso em: 20 de jul. 2016.

MARTINS, J. de S. A chegada do Estranho. São Paulo: HUCITEC, 1993.

PALHETA DA SILVA, J. M. Território e mineração em Carajás. Belém: GAPTA-UFPA, 2013.

PINTO, L. CVRD, a sigla do enclave na Amazônia: as mutações da estatal e o estado imutável no Pará. Belém: Editora CEJUP, 2003.

PINTO, L. Carajás, o ataque ao coração da Amazônia. Belém: Editora Marco Zero e Studio Alfa Fotoletra e Editora, 1982.

PIRES, E.L.S. As lógicas territoriais do desenvolvimento: diversidades e regulação. INTERAÇÕES Revista Internacional de Desenvolvimento Local,vol. 8, n. 2, Set. 2007. Disponível em: <http://www.scielo.br/ scielo.php?script=sci_arttext\&pid=S1518-70122007000200002>. Acesso em: 24 de jul. 2016.

RODRIGUES, J. C. Produção das desigualdades socioespaciais em cidades médias amazônicas: análise de Santarém e Marabá, Pará. 2015. 270 f. Tese (Doutorado em Geografia) - Faculdade de Ciências e Tecnologia, Universidade Estadual Paulista "Julio de Mesquita Filho", Presidente Prudente, 2015.

VALE. Projeto Ferro Carajás S11D. Um novo impulso ao desenvolvimento sustentável do Brasil. Vale, 2012 VALE. A Vale em Parauapebas. Vale: Relatório, 2014. Disponível em: $<$ http://www.vale.com/pt/aboutvale/ sustainability/links/linksdownloadsdocuments/relatorio-vale-parauapebas-2014.pdf > Acesso em: 24 jul.2016.

VILLA VERDE, R. B. R; ALAMINO, R. C. J; FERNANDES, F. R. C. Os desafios da extração mineral na Região Norte em prol do desenvolvimento socioeconômico.In:FERNANDES, F. R. C.; ALAMINO, R. de C. J.; ARAUJO, E. R. (Eds.). Recursos minerais e comunidade: impactos humanos, socioambientais e econômicos. Rio de Janeiro: CETEM/MCTI, 2014, 392p.(pp. 13-21).

VELHO, O. G. Frente de expansão e estrutura agrária: estudo do processo de penetração numa área da Transamazônica [online]. Rio de Janeiro: Centro Edelstein de Pesquisas Sociais, 2009, 172p. Disponível em: <http://books.scielo.org>. Acesso em: 06 nov. 2016. 